\title{
カーボンナノチューブ分散技術総論
}

\author{
中 嶋 直 敏・白木 智 丈
}

\section{Solubilization Technologies of Carbon Nanotubes}

Naotoshi NAKASHIMA and Tomohiro SHIRAKI (Graduate School of Engineering, Kyushu University, 744 Motooka, Nishi-ku, Fukuoka 819-0395, Japan)

Carbon nanotubes (CNTs) have been central materials in the field of nanotechnology and nano-materials science due to their remarkable physical, physicochemical, thermal, mechanical and electrical properties. One of the key issues in the utilization of such seminal materials for basic researches together with the material applications is to develop a methodology to solubilize/disperse them in solvents since as-synthesized CNTs form tight bundled structures due to their strong van der Waals interaction $(0.9 \mathrm{eV} / \mathrm{nm})$ and are insoluble in many solvents. Solubilization/dispersion techniques can be categorized mainly into two methods, namely, 'chemical' and 'physical' modification. Solubilization/ dispersion of CNTs based on the physical adsorption of dispersant molecules possesses several advantages such as the ease of preparation process and maintaining the intrinsic CNT properties, which show sharp contrast with the chemical modification. In this review article, general strategies for CNT solubilization as well as the applications of solubilized CNTs are described.

(Received on September 2, 2015)

Key Words : Carbon Nanotubes, Solubilization, Physical Modification, Interaction, Selective Sorting, Semiconducting, Metallic

1. はじめにーカーボンナノチューブの基本特性一

カーボンナノチューブ（CNT）はグラフェンシートを 円筒状に丸めた構造をしており, 単層カーボンナノチュー ブ（SWNT），2層カーボンナノチューブ（DWNT)，多層 カーボンナノチューブ（MWNT）に分類される（図 1). SWNTは直径 0.5 数 $\mathrm{nm}, \mathrm{MWNT}$ は $100 \mathrm{~nm}$ である. 長さは一般的には数百 $\mathrm{nm}$ 数百 $\mu \mathrm{m}$ であり, 様々な直径, 長さ分布をもつ混合物として得られる.

SWNTの巻き方を「カイラリテイ」と呼ぶ ${ }^{1,2)}$. SWNT の電気物性, 光学物性はカイラリテイの違いにより異なる

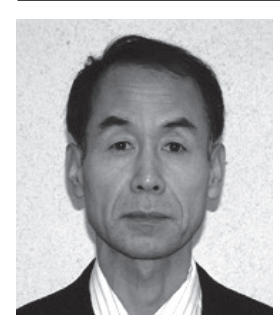

中嶋 直敏; 九州大学大学院工学研究院 応用化学 部門（率819-0395 福岡市西区元岡 744）教授. 昭 和 55 年 3 月, 九州大学大学院工学研究科博士課程単 位修得退学. 昭和 55 年 4 月, 九州大学工学部助手. 昭和 57 年 5 月, 九州大学工学部助教授. 昭和 62 年 5 月, 長崎大学工学部助教授. 平成 5 年 4 月, 長崎大 学工学部教授. 平成 13 年 4 月, 長崎大学大学院生産 科学研究科物質科学専攻教授, 平成 16 年 4 月, 九州 大学大学院工学研究院 教授. 専門は, ナノカーボ ン科学, 超分子科学.
ためにベクトル表示を用いて区別する．SWNTの展開図 において原点（基準点）と重ねる点を決めることにより, 一義的にSWNTのタイプを決める. ベクトル表示で, aベ クトルと $\mathrm{b}$ ベクトルを定義し，そのSWNTを $(n, m)$ SWNTと $2 つ の$ 数字列を用いて表記する。この $(n, m)$ をカイラル指数と呼ぶ．巻き方や直径は，カイラリテイの 違いにより異なる.n-mが3の倍数の時 SWNTは金属性 を，それ以外は半導体性を示す。 $(n, n)$ のSWNTをアー ムチェア型，(n，0）をSWNTをジグザグ型，それ以外の SWNTは，らせん型（キラル型）である.

CNT は直径が数nmで, 長さが数マイクロメートルに

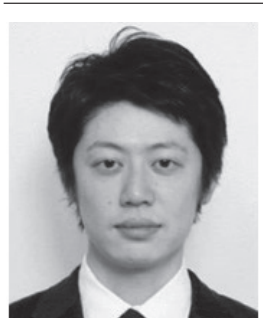

白木 智丈; 九州大学大学院工学研究院 応 用化学部門 (分子) ( T 819-0395 福岡県福岡 市西区元岡 744）助教. 博士（工学）。平成 20 年, 九州大学大学院工学府物質創造工学専攻 卒業. 専門は, 高分子化学, 超分子化学. 

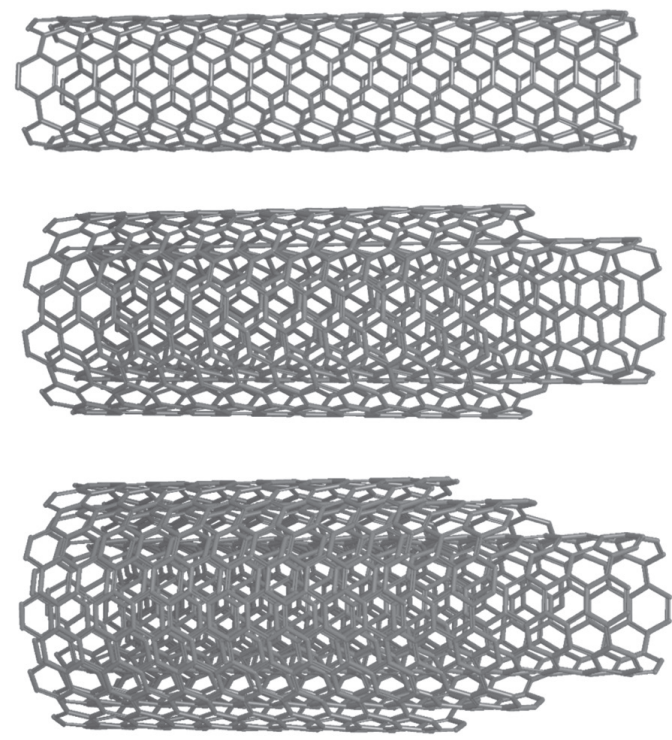

図 1 CNT の構造（上）SWNT，（中）DWNT，（下）MWNT

表1 CNT の特性

\begin{tabular}{|c|c|c|c|}
\hline & SWNT & MWNT & 比較物質 \\
\hline $\begin{array}{c}\text { ヤング率 } \\
{[\mathrm{GPa}]}\end{array}$ & 1000 & $270-950$ & $\begin{array}{c}180-240 \\
(\text { 鋼鉄) }\end{array}$ \\
\hline $\begin{array}{c}\text { 引張強度 } \\
{[\mathrm{GPa}]}\end{array}$ & $13-53$ & $11-150$ & $\begin{array}{c}0.38-1.55 \\
(\text { 鋼鉄) }\end{array}$ \\
\hline $\begin{array}{c}\text { 破断点伸度 } \\
{[\%]}\end{array}$ & 16 & $15.6-17.5$ & $\begin{array}{c}15-50 \\
(\text { 鉄鋼) }\end{array}$ \\
\hline $\begin{array}{c}\text { 熱伝導率 } \\
{[\mathrm{W} / \mathrm{mK}]}\end{array}$ & \multicolumn{2}{|c|}{3000} & $\begin{array}{c}420 \\
(\text { 銀 })\end{array}$ \\
\hline $\begin{array}{c}\text { 密度 } \\
{\left[\mathrm{g} / \mathrm{cm}^{3}\right]}\end{array}$ & $1.3-1.5$ & $1.8-2.0$ & $\begin{array}{c}0.9-1.5 \\
(\text { 高分子) }\end{array}$ \\
\hline $\begin{array}{c}\text { 比表面積 } \\
{\left[\mathrm{m}^{2} / \mathrm{g}\right]}\end{array}$ & $\begin{array}{c}1900 \text { (開端前) } \\
2700 \text { (開端後) }\end{array}$ & 直径に依存 & $\begin{array}{c}1000-3500 \\
\text { (活性炭) }\end{array}$ \\
\hline
\end{tabular}

及ぶため, アスペクト比（〜数千）が極めて大きく, 特異 な $\pi$-共役多環縮合構造により突出した機械的強度, 電気伝 導度, 熱伝導度, 光特性を有する（表1）。炭素のみから 構成されるために比重は $1.3 \sim 2.0 \mathrm{~g} / \mathrm{cm}^{3}$ 程度と鋼の〜 1 ／5と非常に軽い。これらCNT一本における優れた物性 を効率的に新規材料に反映させ，実用化につなげることが CNT研究で重要である.

CNTの極めて大きな魅力の一つが，その優れた機械的 強度である. SWNTでおよそ弾性率 $1 \mathrm{TPa}$, 引っ張り強 度 13 - $53 \mathrm{GPa}$, 破断点伸度 $16 \%$, MWNTで弾性率 $270-$ 950TPa, 引っ張り強度 $11-150 \mathrm{GPa}$, 破断点伸度 16\%で ある.これらの值は表 1 に示すように金属材料と比較して 優れており，「史上最強」の物質である。同じカーボン系 材料として，近年急速に普及が進展している炭素繊維（カ ーボンファイバー）の物性值（弾性率：900 GPa，引っ張 り強度： $6.4 \mathrm{GPa}$, 破断点伸度 : $2.2 \%$ ）より圧倒的に優れ ている.

熱伝導度は, CNTが金属材料を凌駕する物性の一つで ある．円筒構造という特徵的な構造から，熱伝導のキャリ アであるフォノンの散乱が抑制され, 一次元構造上を長距 離にわたって熱を伝播させることができ, SWNT,
MWNTともに 1 本単独では $3,000 \mathrm{~W} / \mathrm{mK}$ の熱伝導性を示 す (理論值 $6,000 \mathrm{~W} / \mathrm{mK}$ ).

CNTは共役系高分子であり，その発達しだ共役により 吸収が赤外波長域まで拡張している。 SWNT一本一本は 特長ある光吸収挙動を示す.SWNTは一次元性形状のた めにバンド構造が量子化したファンホーブ特異点と呼ばれ る状態密度が特異的に高いバンド構造を示す。

\section{CNT 可溶化の重要性}

CNTは突出した特性, 機能をもつ 1 次元導電性分子ナ ノワイヤーであるが，固体状態では強い $\pi-\pi$ 相互作用やフ アンデアワールスカにより束 (バンドル) 構造体を形成 し, 水や汎用の溶媒には分散困難である. 水や有機溶媒中 での超音波照射により分散できるが，超音波照射を止める と, すぐさまバンドル状態に戻る。CNTを溶媒に分散可 能にするためにはCNTの溶媒和を手助けする「可溶化剂」 が必要になる。これによりCNTの利用, 応用は飛躍的に 広がる. CNTの可溶化はCNTの基礎研究, 応用研究への キーサイエンス・テクノロジーである ${ }^{1-9)}$.

\section{3. 化学修飾可溶化（共有結合による可溶化処理）}

溶媒和を可能にする官能基を共有結合的にCNT 表面に 導入する手法が化学修飾可溶化である。これまでに多彩な 化学修飾法が報告されている（詳細は文献 1 - 8 を参照し て頂きたい)。共有結合による化学修飾は, 修飾の度合い にもよるが，CNTを形成する結合を切断するのでCNTが もつ本来の性質が失われる可能性があるので留意が必要で ある。

最も一般的な手法は，CNTの強酸処理による表面酸化 である。強酸 $\left(\mathrm{H}_{2} \mathrm{SO}_{4} / \mathrm{HNO}_{3}=3 / 1 \mathrm{v} / \mathrm{v}, 40-70{ }^{\circ} \mathrm{C}\right)$ 中 でCNTに超音波照射を行うと, カルボン酸が導入された 酸化CNTが合成できる。導入されたカルボン酸は水への 親和性を高め（特に $\mathrm{pH} 5$ 以上），水への分散を容易にする とともに，これを利用して様々な置換基をCNTに導入で きる。

\section{4. 物理修飾可溶化（非共有結合による可溶化）}

\section{1 概要}

非共有結合的な可溶化分子の導入方法としては, 疎水性 相互作用を利用する手法と, 正味の引力的相互作用を用い て吸着させるアプローチに大別される，前者による可溶化 は「ミセル可溶化」, 後者は「物理吸着可溶化」である。 それらの特徴を表 2 によめた。

\section{2 低分子系CNT可溶化剂}

種々の界面活性剂，例えばドデシル硫酸ナトリウム (SDS), ドデシルベンゼン硫酸ナトリウム (SDBS), 膜夕 ンパク質可溶化剤として知られているコール酸ナトリウム 
表2 物理修飾によるCNT 可溶化の分類と特徴

\begin{tabular}{|c|c|c|c|c|}
\hline 可溶化剤 & \multicolumn{2}{|c|}{ 低分子系 } & \multicolumn{2}{|c|}{ ポリマー系 } \\
\hline 可溶化手法 & $\begin{array}{l}\text { ミセル } \\
\text { (水系) }\end{array}$ & 物理吸着 & ミセル & 物理吸着 \\
\hline $\begin{array}{c}\text { 分子間相互 } \\
\text { 作用 }\end{array}$ & $\begin{array}{c}\text { 疎水性相互 } \\
\text { 作用 }\end{array}$ & $\begin{array}{l}\pi-\pi, \text { CH- } \pi, \\
\text { ファンデル } \\
\text { ワールス相 } \\
\text { 互作用 }\end{array}$ & $\begin{array}{c}\text { 疎水性相互 } \\
\text { 作用 }\end{array}$ & $\begin{array}{l}\pi-\pi, \text { CH- } \pi \text {, } \\
\text { ファンデル } \\
\text { ワールス相 } \\
\text { 互作用 }\end{array}$ \\
\hline $\begin{array}{l}\text { 代表的な } \\
\text { 分子 }\end{array}$ & $\begin{array}{c}\text { 界面活性剤 } \\
\text { 分子 }\end{array}$ & $\begin{array}{l}\text { ピレン, ポ } \\
\text { ルフィリ } \\
\text { ン, コレス } \\
\text { テロール }\end{array}$ & $\begin{array}{l}\text { 高分子電解質, } \\
\text { 両 親媒性ブロロ } \\
\text { ック共重合体 }\end{array}$ & $\begin{array}{l}\text { DNA, 糖, } \\
\text { 芳香族ポリ } \\
\text { マー, 共役 } \\
\text { 系ポリマリー }\end{array}$ \\
\hline 特 & $\begin{array}{l}\text { 除去可能 } \\
\text { 大過剩必要 }\end{array}$ & 除去困難 & \multicolumn{2}{|c|}{$\begin{array}{l}\text { 効率的可溶化可能 } \\
\text { 除去困難 }\end{array}$} \\
\hline
\end{tabular}

(SC)，デオキシコール酸ナトリウム（DOC）などのステ ロイド系界面活性剤などがミセル可溶化剤としてよく使わ れる.これらのミセル水溶液中にSWNT（固体）を入れ， 超音波照射（バス型あるいはチップ型），次に超遠心機に よる不溶部の分離により SWNT溶解・分散溶液が得られ る. 一般に $100000 \times g$ 以上での超遠心操作で, 孤立溶解 SWNTが調製できる，可溶化のメカニズムとして，超音 波照射により界面活性剂分子がCNTバンドル内に入り込 み，ジッパーを外すようにバンドルをほどき，界面活性剤 が形成するミセルの疎水性内部空間にCNTが内包され, 孤立溶解が達成される，というモデルが受け入れられてい る.

筆者らは多環芳香族基を有する有機分子が $\pi-\pi$ 相互作 用により強くCNT表面に物理吸着し，優れたCNT 可溶化 剤となると考えた。すなわち，図2に示すように，「多環 芳香族基に極性基を連結すれば水中での可溶化が，疎水基 を連結すれば有機溶媒での可溶化が可能となる」というコ ンセプトを提案した ${ }^{10)}$ 。このコンセプトの実証のために,
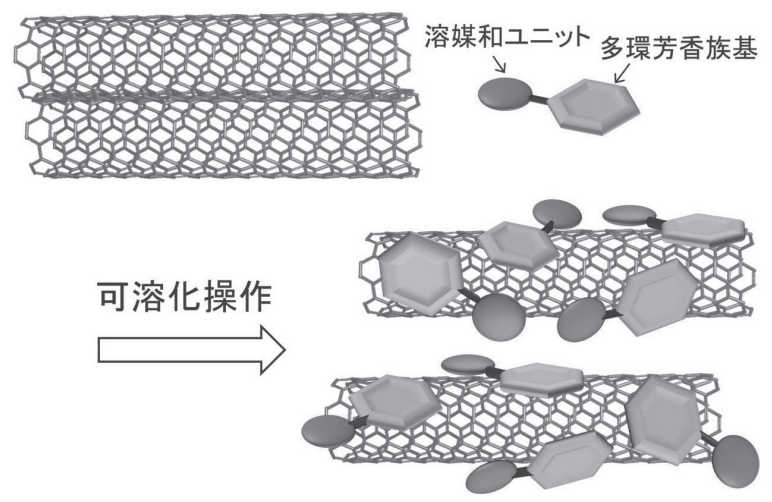

図2 多環芳香族基をもつ分子によるカーボンナノチュー ブ可溶化のイメージ

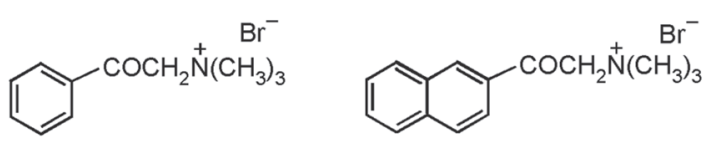

図3に示すように, ベンゼン, ナフタレン, フェナンスレ ン, ピレンをCNT吸着ユニットとし，極性基としてアン モニウム塩を連結した化合物を合成し, これらを用いて水 中でのSWNT可溶化能を検証した。 その結果フェニル基, ナフチル基をもつ化合物は可溶化を示さず, フェナンスレ ンを持つ化合物はわずかに可能化能を示し，ピレンをもつ アンモニウム化合物はSWNTを非常によく溶解すること を見出し，提案のコンセプトが正しいことを示した。その 後, 多彩な化学構造を持つピレン誘導体が合成され, CNT 可溶化に利用されている。 その効率的な吸着ゆえ可 溶化のみならず, 金属ナノ粒子やタンパク質などを CNT に担持する際のリンカー分子としてもピレン誘導体は多く 利用されている. 多核芳香族では, アントラセン, ターフ エニル, ペリレンなどの誘導体も CNTを可溶化する.

筆者らは巨大 $\pi$ 系分子であるポルフィリンも物理吸着可 溶化ユニットとして有効であることを世界に先駆けて報告 した（図4） ${ }^{11)}$ 。ポルフィリンは光合成中心を担う色素と であり, 電気化学や光化学の分野において膨大な研究が行 われている機能性分子である。半導体性 SWNTとの組み 合わせは多くの光誘起電子移動の研究へと展開した.

低分子系の可溶化剤は, CNT上に吸着している可溶化 分子と, バルク溶液中で遊離の状態にある可溶化分子とが 動的な平衡状態にある. したがって透析操作で遊離の可溶 化分子を除去するとバンドル化により CNTが析出する.

\section{3 高分子系 CNT可溶化剂}

高分子系の可溶化剂も低分子系と同様にミセル可溶化剤 と物理吸着可溶化剂に分類できる ${ }^{1-8)}$ 。 ミセル可溶化剂と しては疎水性ユニットと親水性ユニットからなるブロック 共重合体が報告されている。例えばポリスチレン（PS） 一ポリアクリル酸（PAA）ブロック共重合体（PS PAA）によるCNTの水分散系では疎水性PS 部をCNT側 に，親水性PAA 部を水溶液側に向けることでミセル可溶 化が生じる。多くのブロック共重合体によるCNT分散が 報告されているが, 疎水性ユニットとしてはPSが, 親水

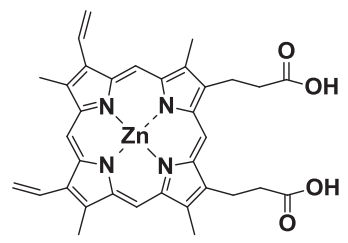

図4 SWNT可溶化を報告した最初のポルフィリンの化学構造式
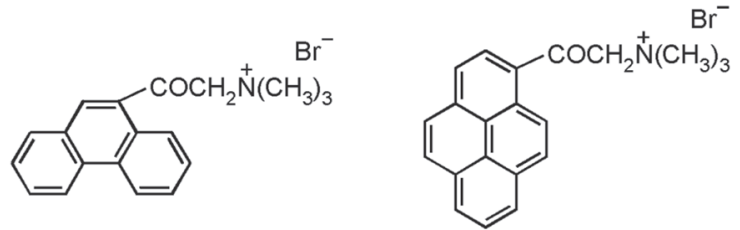

図３アンモニウムブロマイド（水溶性基）をもつ種々の多環芳香族化合物 
性ユニットとしてはポリエチレンオキシド（PEO）部位 をもつものが多い.

物理吸着可溶化剂としては主鎖や側鎖が物理吸着性を示 す高分子が用いられる。代表的なものとしては主鎖が $\pi$ 相互作用により吸着するポリパラフェニレンビニレン誘 導体などの共役系高分子や主鎖の $\mathrm{CH}-\pi$ 相互作用が重要 な役割を果たすカルボキシメチルセルロースやキトサン, ゼラチンが知られている。 また側鎖が物理吸着する高分子 系可溶化剤としてはピレンやアントラセンなどの芳香族ユ ニットを導入したペンダント型共重合ポリマーが，有機溶 媒中でSWNTを孤立溶解させる能力を有する。高分子系 物理吸着可溶化剂の場合, 多点でCNT 表面と相互作用す るために，バルク中に遊離している可溶化剤との交換が遅 くなる．後述するDNAにおいては交換が極めて起こりに くく，遊離したDNAが存在しない状態であっても可溶化 が達成できる。これらの事実は, 高分子可溶化剂と CNT が安定な複合体を生成していることを示し，これまでに多 彩な高分子/CNT 複合体の応用研究が行われている.

筆者らはスーパーエンジニアリングプラスチックである 機能性高分子の中から高分子系可溶化剂を探索し, 高分子 /CNT複合体の高機能化に関する研究を展開している ${ }^{1-8)}$. ポリベンズイミダゾール（PBI）は耐熱性高分子であり, ポリイミド (PI) は, 電子材料用部材として実用化されて いる高分子である。図5に示したスルホン酸塩型全芳香族 $\mathrm{PI}(\mathrm{PI}-1)$ は, ジメチルホルムアミド $(\mathrm{DMF})$ やジメ チルスルホキシド（DMSO）などの溶媒中でSWNTを極 めて高効率に可溶化する（可溶化量はポリイミド $1 \mathrm{mg}$ で $3 \mathrm{mg}$ のSWNTを可溶化できる). このような高濃度にお いて溶液はゲル化するが, 孤立溶解 SWNTとほほ同じピ ークをもった近赤外吸収スペクトルを示す.PBIもSWNT を完全に孤立状態までバンドルを解いて可溶化できる. $\mathrm{PI} / \mathrm{CNT}$ 複合体からは超高強度材料が, $\mathrm{PBI} / \mathrm{CNT}$ 複合体 からはエネルギー材料の創製が期待できる.

\subsection{DNA/RNAによるCNT 可溶化}

CNT科学において大きな研究領域を形成している高分 子系可溶化剂があり，それがDNAである。2003年に筆者 ら ${ }^{12)}$ は二本鎖DNAが（図6），また，ほぼ同時にZheng ら ${ }^{13)}$ らは一本鎖 DNA がSWNTを溶液中に安定に分散さ せることを見出し，この複合材料は多くの分野で注目を集 めている。一本鎖 DNA と CNTは, DNA 塩基との $\pi$ - $\pi$ 相 互作用や $\mathrm{NH}-\pi, \mathrm{CH}-\pi$ 相互作用により吸着しているこ とが計算解析から提案された。二本鎖DNAでは，超音波
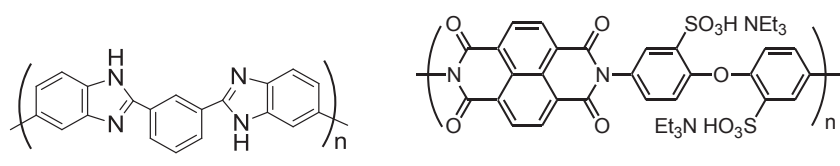

図5 PBI (左) と PI-1 (右) の化学構造式
処理の際に部分的に解けたDNA 鎖の塩基対とSWNTによ る $\pi-\pi$ 相互作用や，二本鎖 DNAの主溝とSWNT の相互 作用により可溶化が進行すると推定される. DNA/CNT 複合体に関しては，これまでに細胞取り込みやドラッグデ リバリーシステムなどのバイオ応用を中心として多くの報 告がある. DNAによるCNT可溶化は極めて安定で, サイ ズ排除クロマトグラフィ（SEC）により存在する過剩な DNA（フリーDNA）とDNA/SWNT複合体を分離し, 単離したフリーのDNAを含まないDNA/SWNT複合体の 安定性をSECに再度注入するという手法で評価した実験 で, 単離後 1 力月後においても複合体からのDNAの解離 は見られなく, 10 量体程度のオリゴDNAで充分安定なハ イブリッドを形成することがわかった。こうした高い複合 化安定性は，CNTのバイオ分野への応用に重要である.

この吸着特性を利用して我々は, DNAとの置換反応の サーモダイナミクス (熱力学) パラメーターの算出に成功 してきた ${ }^{14)}$.

\section{5. 半導体性 SWNT と金属性 SWNT の分離}

一層のSWNTは, 半導体性 SWNT と金属性 SWNT の 混合物であり, これらの特性は大きく異なるので, 利用分 野が異なる。従って，これらの分離が重要となる。分離法 として，i）化学反応を利用した分離法, ii ) ブレークダ ウン法, iii）クロマトグラフィー法, iv）密度勾配超遠心 分離 (DGU) 法, $\mathrm{v}$ ) 分子認識法, およびvi）動的超分 子の利用による分離, が挙げられる ${ }^{1-9)}$.

i ）は, 金属性SWNT と半導体性SWNT の化学反応性 の違いを利用したものである。 ii ) は，電極間にSWNT を配置し過電流を流すことで金属性SWNTを選択的に「焼 き切る」方法である。 iii）は，ゲルクロマトグラフィを利 用した分離である。産総研の片浦らは, アガロースゲル電 気泳動（これはDNAの分離に利用されている方法）で, 金属性SWNT と半導体性SWNT の分離が可能であること を示した ${ }^{15)}$. 後に電場印加なしでアガロースゲルを“絞 る’だけでも金属性 SWNT溶液が得られることが報告さ れた，彼らはこの方法を発展させ，アガロースゲルを用い たカラムクロマトグラフィーによる半導体性・金属性 SWNTの分離を開発し（図7a）大量分離への道を拓いた。 iv）の密度勾配超遠心分離法（DGU法）は, 密度勾配に よって試料の沈降速度の差を拡大させ, あるいは遠心力と

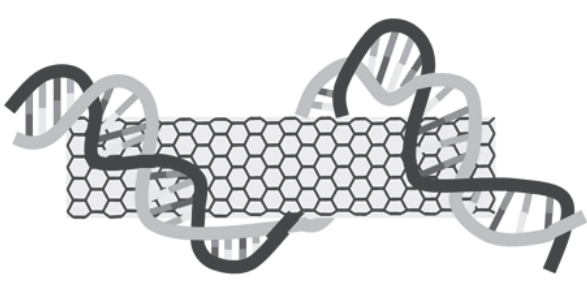

図6 DNA/SWNT複合体の模式図 
浮力とがつりあう密度が同じ場所に粒子のバンドを作るこ とによって，分離を行う方法であり（図7b), Hersamら はこれをCNT分離に応用した ${ }^{16)}$. 現在ではこの方法で分 離されたそれぞれのSWNTが市販されている．現在DGU 法は, その高い分離能から多くの研究者に注目され利用さ れているが, 不純物として密度勾配用試薬である iodixanol（コストも高い）を含み，精製が必要という欠点があ る.

v）の分子認識法を用いた分離は, SWNT可溶化剂の 「分子認識」を利用するものである。 2007 年に選択的可溶 化能をもつ高分子が2つのグループからほぼ同時に報告さ れた ${ }^{17-18)}$. どちらもポリフルオレン (polyfluorene ; PFO）やPFO交互共重合ポリマー（図8a）が半導体性 SWNTのみを可溶化するという報告であった。これらは, 半導体性SWNTの高選択的可溶化を示す最初の論文であ り, 非常にセンセーショナルであった. 選択性発現メカニ ズム, すなわちなぜ半導体SWNTのみを認識, 溶解する のか謎が多い点がさらに研究者の好奇心を集め, 次々と選 択性を示す新たな PFO交互共重合体が報告された（図 8b)、筆者らはPFOランダム共重合体（図8c）においても 選択性を確認し，共重合比によってもカイラリティ分布が

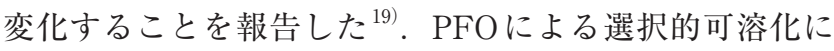
は強い溶媒依存性があり, 芳香族溶媒であるトルエン, キ シレンおよびそれらの類縁体を溶媒として用いた時は選択 性が見られる。ただし，収率は極めて低く，大量分取には
不向きである。それでも純度の高さは魅力的で, 金属性 SWNTの混入のために阻まれていたSWNTの半導体デバ イス開発への道を開いたといえる，例えば，半導体性 SWNTは高いオン/オフ比と移動度をもつ電界効果型トラ ンジスタ（FET）の作製へ有望な材料であることが知ら れており，オン/オフ比 $>10^{5}$ と非常に大きい. 筆者らは, 金属ナノ粒子を担持可能なチオール基やポルフィリン基を もつ PFO共重合体を合成し（図8d）, 金属ナノ粒子を SWNTの長さ方向に沿って配列できることを示した ${ }^{20)}$.

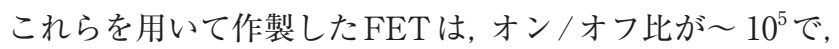
デバイスの移動特性は, 金属ナノ粒子の有無で変化するこ とを報告した. Arnoldらは PFO/半導体性SWNTを太陽 電池に組み込むことで近赤外光からのエネルギー取り出し に成功した ${ }^{21)}$ 。これにより従来の色素では回収できなかっ た近赤外領域の太陽光エネルギーを回収できることを示し た. 応用はFETにとどまらない. 今後の展開が期待でき る.

vi）は，筆者らが最近開発した「可溶化剂フリーの高効 率分離法」である ${ }^{22)}$. 分子設計の指針として, 第一に半導 体性選択性を付与すること, 第二に可溶化剂が除去可能で あること, そして第三に可溶化剤の再利用を達成すること を目的とした（図9). 分子デザインとしては, アルキル 側鎖を 9,9'-位にもつフルオレンの 2,7-部位に, 金属配位部 位として1,10-フェナントロリンをSonogashiraカップリン グで $\pi$ 共役を保ちつつ導入することで半導体選択性を狙っ

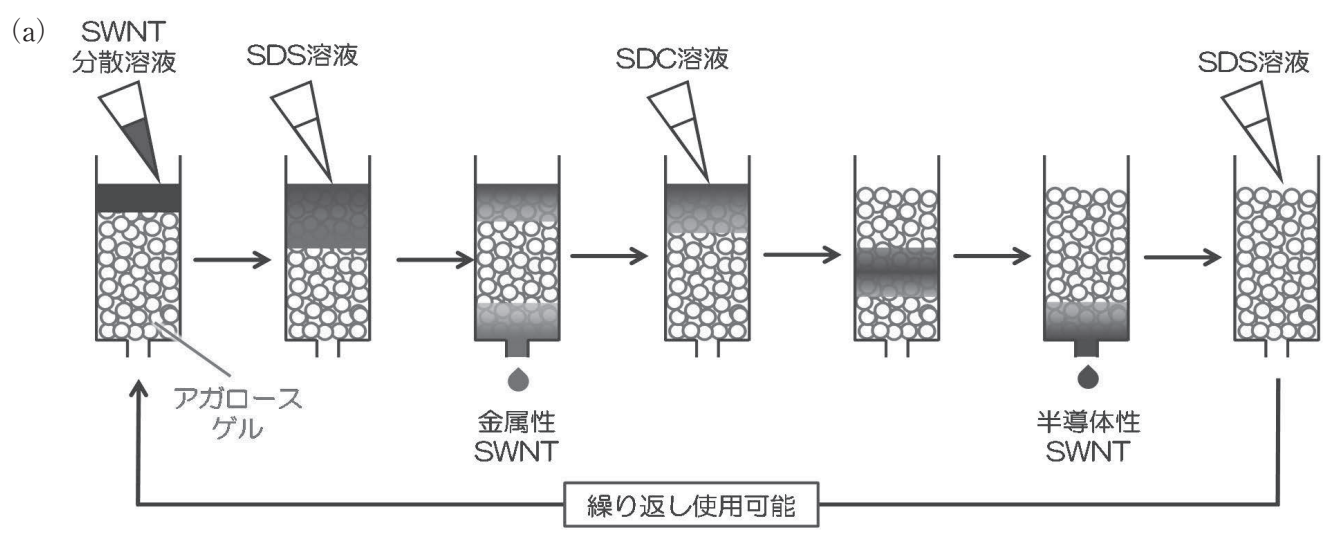

(b)

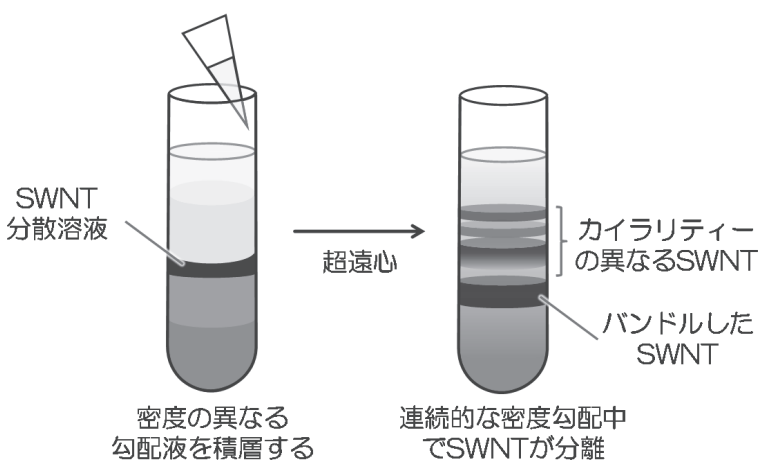

図7 半導体性／金属性SWNT分離操作のスキーム（概念図）

（a）クロマトグラフィー法を使った分離法，（b）DGU法にもとづく分離法 
a)

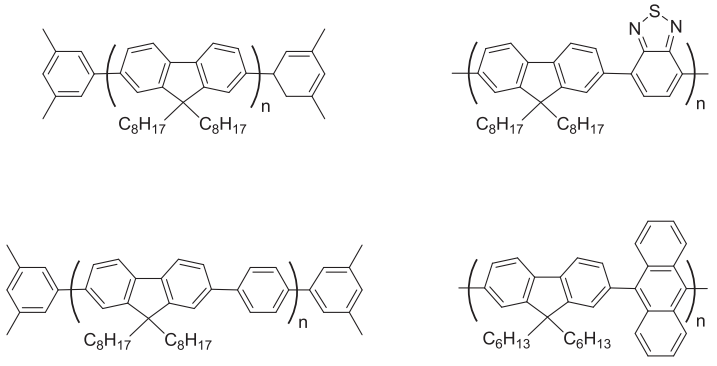

b)
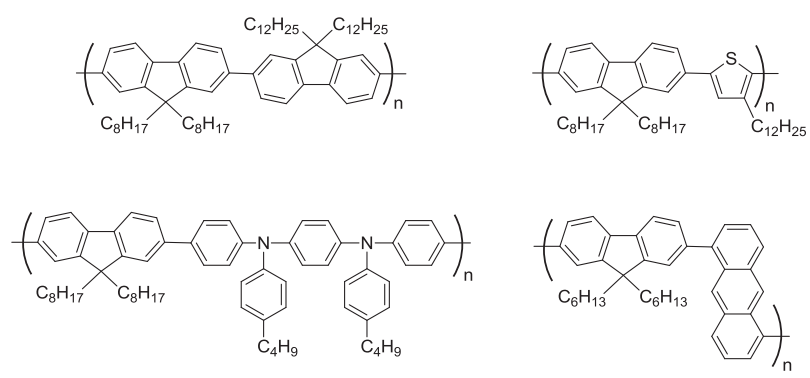

c)

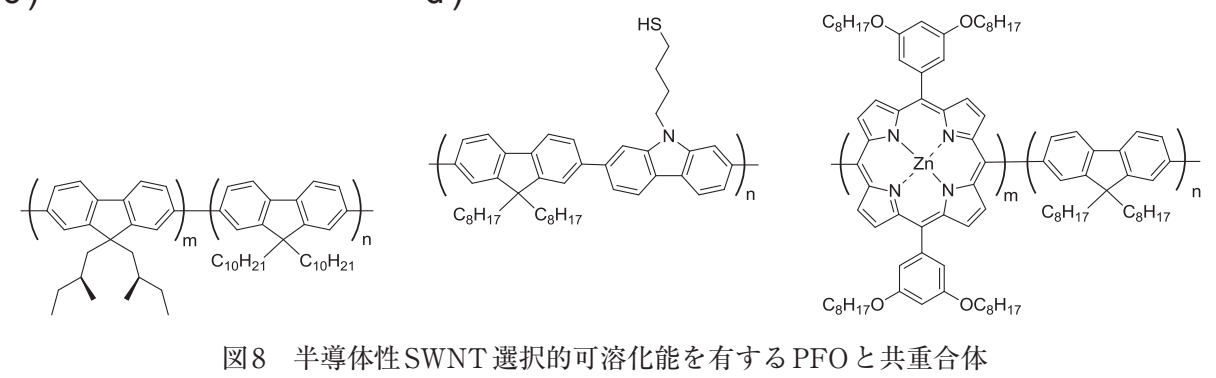

d)

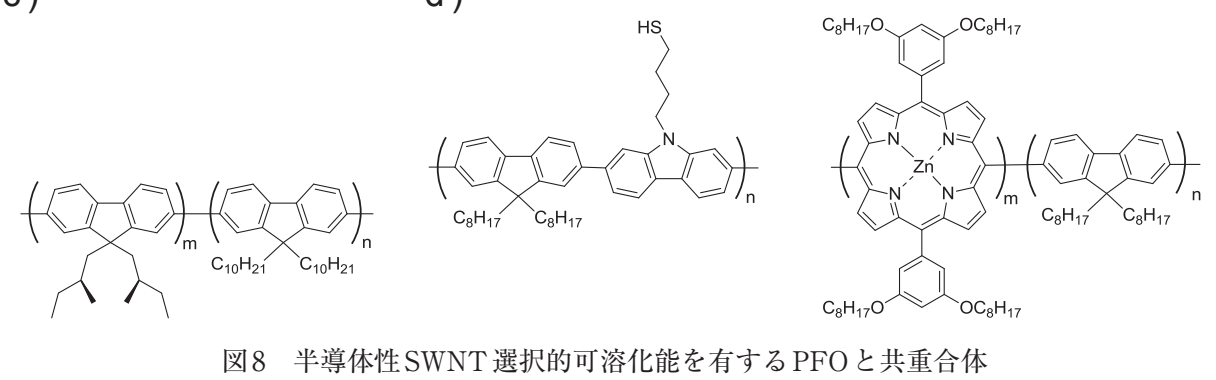

図8 半導体性 SWNT 選択的可溶化能を有する PFO と共重合体

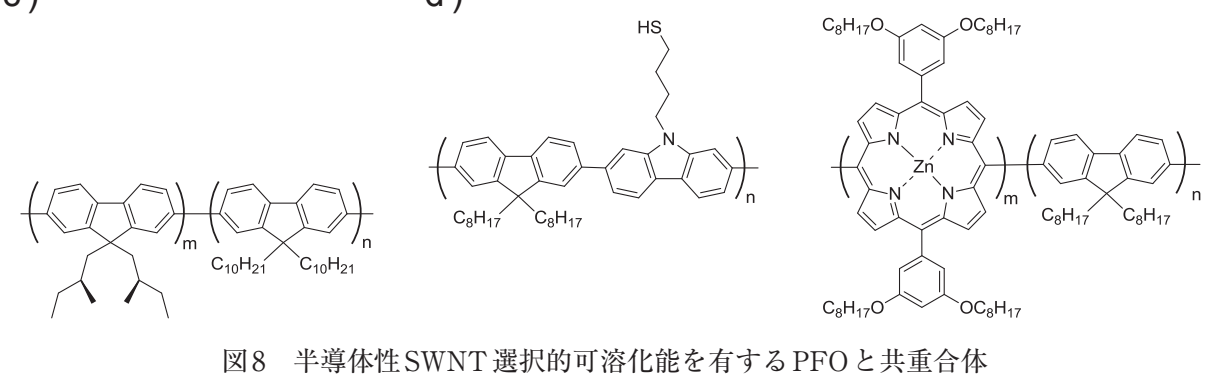

た。ここでは，超分子ポリマーの最終的な形状を直線型と する. 最大の特徴である可溶化剤の除去は, 超分子の可逆 な結合の利用という特徵に基づいた単純明快な手法であ る。ここでは，フェナントロリンの窒素原子を酸添加によ りプロトン化することで, 超分子ポリマーの解離を行っ た.トリフルオロ酢酸を用い, 配位子に対して過剩量の酸 添加を行ったところ，速やかに黒い沈殿が生成し，これを 滤過抢よび洗浄することで，可溶化剂を除去した半導体性 SWNTを固体として得られる。剥離された可溶化㓮につ いては，配位子を中和し，簡単に再生することができ，そ のまま新たな可溶化実験に利用することができる.

半導体性 SWNT の選択的な可溶化法とそれに引き続く 可溶化剂の除去方法の確立は, 実用的な視点から見ても, SWNTの半導体デバイス応用への道を開いたといえる. 超分子化学的手法の導入は, 半導体性 SWNT の化学的精 製にとどまらず，バラエテイ豊かな金属錯体のもつ配位構 造を利用した，精密なカイラリテイ認識能制御の可能性を 示したものである.

6. ま と め

CNT の溶媒（溶剤）への可溶化, 機能化研究が始まり, 約 15 年が経過し, この間に研究はめざましく進展した. 可溶化 (分散) CNT (CNTインク) は, CNTの応用展開 の鍵を握っており, 既存の複合材料では到達できない物 性・機能を示す新しいナノ複合材料を創製する ${ }^{23-26)}$. 少 量のCNT添加でも導電性の付与や機械的強度の増大した 多岐にわたるナノ複合材料が創製できる.CNTを材料と した燃料電池触媒への応用展開も進展しており ${ }^{24-26)}$, 透 明導電性CNT フィルムも実用化／市場展開が進行中であ る. 可溶化を基盤とした金属性SWNT と半導体SWNT の 利用により, 更なる高機能化, 高性能化がデインでき, デ バイス分野でのブレークスルーが期待できる.

可溶化CNTは, CNTの基礎科学に於いても重要である. なぜなら，可溶化CNTの利用によりに，個々のカイラリ ティのSWNTの電子準位（酸化電位, 還元電位, フェル ミ準位，仕事関数）を精密に決定できるからである．さら に，正及び負のトリオン（電荷を持ったエキシトン）の存 


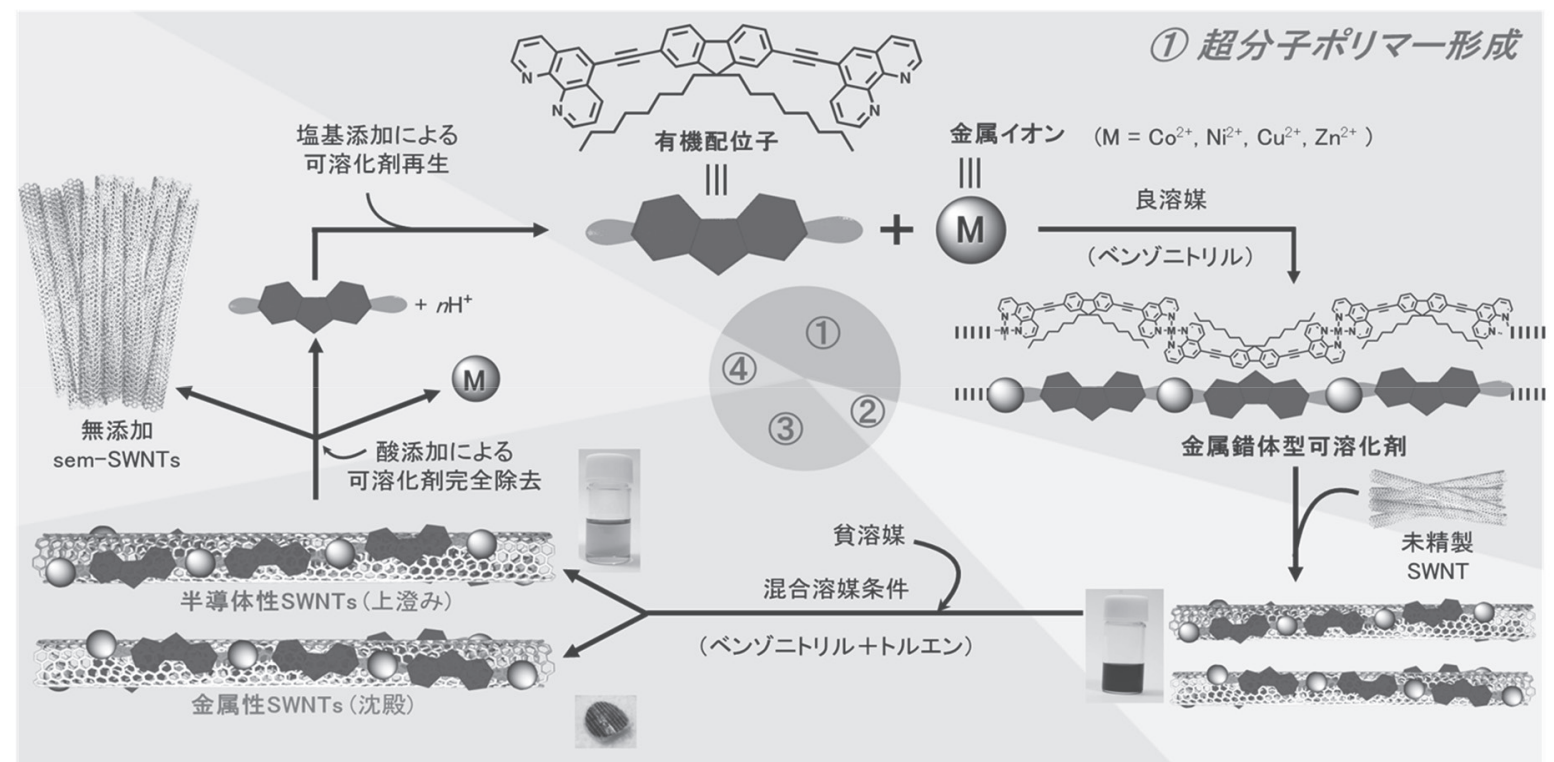

図9 超分子型可溶化剂を用いたSWNTの半導体性カイラリテイ選択的可溶化のサイクル

在も可溶化CNTの利用により明らかになった.

このように，CNTは，溶媒への分散／溶解により，実 に多彩な分野への応用，用途展開が可能であり，実用化へ 向けた研究は，今後ますます加速すると思われる。

\section{Reference}

1) Nakashima, N.; Fujigaya T.: Chem. Lett., 36, 692-697 (2007)

2) Fujigaya, T.; Nakashima, N.: Poly. J. (Review article), 40, 577589 (2008)

3 ) Fujigaya, T.; Nakashima, N.: J. Nanoscience Nanotechnol. 12, 1739-1747 (2012)

4 ) Nakashima, N.: "Takanhoukouzoku Bunshi niyoru Kabonnanotyubu no Kayouka Kinouka”, "Kogyouyou Tanso Zairyo, Nano Kabon Zairyou no Hyoumensyori”, (in Japanease) Gijyutu Jyouhou kyoukai ed., Tokyo, pp.89-95 (2011)

5 ) Nakashima, N.; Fujigaya T.: “Kabon Nanotyubu Gurafen”, Saisentan Zairyou Sisutemu, 1st, Society of Polymer Science Japan ed., Kyoritu Syuppan, Tokyo (2012)

6 ) Nakashima, N. ed.: "Kabon Nanotyubu Gurafen Bunsan Gijyutu no Kougyouka to Kinoutenkai”, S\&T Publishing, Tokyo, PP.1133 (2014) Fujigaya, T.; Nakashima, N.: Sci. Technol. Adv. Mater., 16, 024802-024823 (2015)

7 ) Fujigaya, T.; Nakashima, N.: Sci. Technol. Adv. Mater., 16, 024802-024823 (2015)

8 ) Nakashima, N.: “Takanhoukouzoku Bunshi niyoru Kabonnanotyubu no Kayouka Kinouka Denkaishitu heno Ouyou", "Doudensei Fira, Douden Jyozai no bunsansei koujyou, Hyouka, Ouyou”, Gijyutuj Jyouhou kyoukai ed., Tokyo, pp.269-273 (2015)

9 ) Toshimitsu, F.; Nakashima, N.: "Koujyundo Handoutaisei Kabon Nanotyubu no Kourituteki Bunri -Dainamiku Tyobunshi Haii Kabaku ni Motozuita Bunrizai no Kaihatsu-”, Kagaku, Kagaku Dojin, 70, 41-44 (2015)

10) Nakashima, N.; Tomonari, Y.; Murakami, H.: Chem, Lett., 31 , 638-639 (2002)

11) Murakami, H.; Nomura, T.; Nakashima, N.: Chem. Phys. Lett., 378, 481-485 (2003)

12) Nakashima, N.; Okuzono, S.; Murakami, H.; Nakai T.; Yoshikawa, K.: Chem. Lett., 32, 456-457 (2003)

13) Zheng, M.; Jagota, A.; Semke Ellen, D.; Diner Bruce, A.; McLean
Robert, S.; Lustig Steve, R.; Richardson Raymond E.; Tassi Nancy, G.: Nat. Mater., 2, 338-342 (2003)

14) Kato, Y.; Inoue, A.; Niidome, Y.; Nakashima, N.: Sci. Rep., 2, article number: 733 (2012)

15) Tanaka, T.; Jin, H.; Miyata, Y.; Kataura, H.: Appl. Phys. Express, 1. 1140011-1140013 (2008)

16) Arnold, M. S.; Green, A. A.; Hulvat, J. F.; Stupp, S. I.; Hersam, M. C.: Nat. Nanotech., 6, 60-65 (2006)

17) Nish, A.; Hwang, J.Y.; Doig, J.; Nicholas, R. J.: Nat. Nanotech., 2, 640-646 (2007)

18) Chen, F.; Wang, B.; Chen, Y.; Li, L.-J.: Nano Lett., 7, 3013-3017 (2007)

19) Ozawa, H.; Fujigaya, T.; Niidome, Y.; Hotta, N.; Fujiki, M.; Nakashima, N.: J. Am. Chem. Soc., 133, 2651-2657 (2011)

20) Ozawa, H.; Yi, X.; Fujigaya, T.; Niidome, Y.; Asano T.; Nakashima, N.: J. Am. Chem. Soc., 133, 14771-14777 (2011)

21) Bindl, D. J.; Wu, M.-Y.; Prehn, F. C.; Arnold, M. S.: Nano Lett., 11, 455-460 (2010)

22) Toshimitsu, F.; Nakashima, N.: Nat. Commun., 5, 5041 (2014)

23) Fukumaru, T.; Fujigaya, T.; Nakashima, N.: Sci. Rep., 5, art no. 7951 (2015)

24) Berber, M. R.; Fujigaya, T.; Sasak, K.; Nakashima, N.: Sci. Rep., 3, art. no. 1764 (2013)

25) Hafez, I. H.; Berber, M. R.; Fujigaya, T.; Nakashima, N.: Sci. Rep., 4, art no.6295 (2014)

26) Yang, Z.; Nakashima, N.: Sci. Rep., 5, art no. 12236 (2015)

\section{日本語表記参考文献}

4 ）中嶋直敏：「多環芳香族分子によるカーボンナノチューブの可溶 化機能化」, “工業用炭素材料, ナノカーボン材料の表面処理”, 技術情報協会編，pp.89-95（2011）

5 ）中嶋直敏, 藤ヶ谷剛彦：カーボンナノチューブ・グラフェン, 最先端材料システム第 1 巻, 高分子学会編, 共立出版 (2012)

6 ）中嶋直敏, 監修：カーボンナノチューブ・グラフェン分散技術 の工業化と機能展開, S\&T出版, pp.1-133 (2014).

7 ）中嶋直敏：「多環芳香族分子によるカーボンナノチューブの可溶 化, 機能化, 電解質等への応用」, “導電性フィラー, 導電助剂 の分散性向上，評価，応用”，技術情報協会，pp.269-273（2015）

9 ) 利光史行, 中嶋直敏：高純度半導体性カーボンナノチューブの 高効率分離 -ダイナミック超分子配位化学に基づいた分離剂の 開発一, 化学, 化学同人, 70, 41-44（2015） 